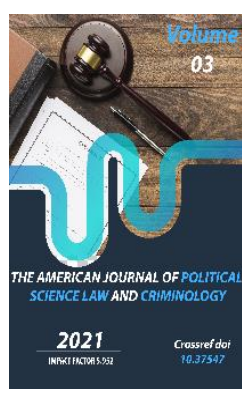

\title{
Intercultural Communication As The Basis Of Socio-Political Stability Of The Country
}

\author{
Sardorbek Diyorov \\ Lecturer Of The Faculty Of International Journalism, Uzbek State University Of World \\ Languages, Uzbekistan
}

Journal Website:

https://theamericanjou

rnals.com/index.php/ta jpslc

Copyright: Original content from this work may be used under the terms of the creative commons attributes 4.0 licence.

\section{ABSTRACT}

Intercultural communication as the most important aspect of intercultural interaction is a prerequisite for a successful dialogue of cultures across the globe. Under the leadership of President of Uzbekistan Shavkat Mirziyoyev, along with the principles of interethnic harmony and religious tolerance in the internal life of the country, a good neighbourly policy is being pursued with neighbouring republics. This article highlights the achievements of the Republic of Uzbekistan in foreign policy in recent years and the establishment of good neighbourly relations between the peoples of Central Asia.

\section{KEYWORDS}

Dialogue of cultures, intercultural interaction, globalization processes, intercultural communication, socio-political stability.

\section{INTRODUCTION}

Theoretical comprehension of the interaction and dialogue of cultures within the framework of modern globalization processes is becoming one of the most important issues of today, as an essential aspect of the modern cultural and historical process and a condition for the stabilization of modern social relations between peoples, countries and civilizations. Intercultural communication as the most important aspect of intercultural interaction is a prerequisite for a successful dialogue of cultures across the globe. The cultural identity of the individual and society is formed and developed in a complex process of dialogical interaction between representatives of ethnic and national cultures, which presupposes the conscious acceptance of certain qualities as their own. Intercultural communication, as a 
socio-cultural phenomenon, was brought to life by the practical needs of the post-war world. Practical needs have arisen as a result of the rapid economic development of many countries and regions, revolutionary changes in technology, the associated globalization of economic activity. As a result, the world has become more interconnected - the density and intensity of long-term contacts between representatives of different cultures have grown and continue to increase. The factor of increasing free time among the masses of people plays a role. In addition to the economy, tourism, education, science, such mechanisms of cultural transmission as libraries and museums have become the most important areas of professional and social intercultural communication. Experience shows that for an adequate perception and assessment of foreign cultural phenomena, it is necessary not only to know the language of the respective culture but also to know the norms, rules, traditions, customs, etc., accepted in it. The decisive factor here is the question of the significance of cultural differences, the ability to realize, understand and accept them in the process of cultural interaction. Thus, the main goal and meaning of the process of cultural interaction is the desire to be understood by your partner, the willingness to communicate as the ability to convey your information, knowledge and experience to everyone who participates in intercultural interaction. The most important aspect of intercultural interaction is intercultural communication and intercultural competence. Even in the educational process of bachelor, the concept of "competence" has now become a key concept. Competence is a set of knowledge, abilities and skills common to all communicants, which in the theory of intercultural communication is called "intercultural competence". Intercultural communication is a term that appeared in domestic humanities relatively recently, revealing an important aspect of the spiritual culture of society.

\section{MATERIALS AND METHODS}

The events of the last decade that have taken place in our country have led to qualitative changes in the social structure of society, the dynamics and nature of the development of the system of social relations, social differentiation in society, the formation of new social groups are taking place at a rapid pace. In the context of difficult socio-economic reforms, the attitude of people towards each other is of great importance at the present stage.

Over the past 4-5 years, Uzbekistan has paid special attention to the observance of democratic principles, the rule of law, protection of socio-political rights of citizens, freedom of thought, speech and religion.

At the same time, this period has gone down in history as a period of great changes in the foreign policy of Uzbekistan. Under the leadership of President of Uzbekistan Shavkat Mirziyoyev, along with the principles of interethnic harmony and religious tolerance in the internal life of the country, a good neighbourly policy is being pursued with neighbouring republics.

Today, Uzbekistan's open, constructive, mutually beneficial foreign policy with foreign countries, especially with neighbouring countries, is of great importance for the countries of Central Asia. The recent visits of the President of Uzbekistan to Turkmenistan, 
Kazakhstan, Russia, China and Kyrgyzstan are a clear example of the special attention paid to mutually beneficial cooperation in the foreign policy of our country.

The stalemate over a foreign policy that has developed over the years began with Shavkat Mirziyoyev's first term as President.

In the paragraph of the Strategy of actions on five priorities of development of the Republic of Uzbekistan for 2017-2021, entitled "Priorities in the field of well-thought-out, mutually beneficial and practical foreign policy": "... formation "is one of the main priorities.

Accordingly, as noted by the President in his speech at the 72nd session of the UN General Assembly on September 19, 2017, a completely new political environment has been created in the region in a short period of time.

The President Sh. Mirziyoyev said: "Today, Uzbekistan attaches great importance to the Central Asian region in its foreign policy. This is a well-thought-out path.

As being located in the heart of Central Asia, Uzbekistan has a direct interest in making the region a region of stability, sustainable development and good neighbourliness.

A peaceful, economically developed Central Asia is the most important goal and the main task we are striving for.

Uzbekistan is a strong supporter of dialogue, practical cooperation and strengthening good neighbourliness.

We are ready to cooperate with the Central Asian countries on all issues, without exception, based on reasonable compromise. "[2]

The signing of the Uzbek-Kyrgyz state border agreement in early September 2017, which prevents border disputes, was a truly significant event as a solution to these issues.

Over the past 4-5 years, the Government and the President of Uzbekistan have adopted several normative and legal acts that serve for positive results in foreign policy. The main purpose of the adopting of the above documents is to expand mutually beneficial, a practical partnerships between the neighbouring countries in political, trade, economic, investment, financial, technical, cultural and humanitarian spheres, and to raise strategic cooperation and allied relations to a qualitatively new level. ensuring enrichment and ensuring the unconditional and full implementation of the agreements reached between the governments.

As a result, to date, Uzbekistan's comprehensive relations with its neighbours in Central Asia have been further developed and fraternal ties have been strengthened. In particular, between the republics, the opportunities for citizens to enter and leave the territory of one country to another have been expanded. As a result, the restrictions imposed for 20-25 years have been lifted, and citizens of Uzbekistan have been able to communicate freely with their relatives in neighbouring countries. In 1924, as a result of the artificial nation-state delimitation in Central Asia, in some regions the population of one village was divided into two, part to Tajikistan, part to Uzbekistan or part to Kyrgyzstan, and part to Uzbekistan. If the distances between these settlements, which were demolished 5-6 
years ago, were a few hundred meters, the relatives would not be able to attend each other's weddings because they were citizens of other countries.

Today, such tragedies have come to an end. Mutual relations were strengthened by sincere bonds of friendship, and centuries-old traditions began to continue again.

This is primarily the result of the prudent state policy pursued by the leadership of Uzbekistan in recent years, adherence to the principles of good neighbourliness.

From the very beginning of his presidency, President of Uzbekistan Shavkat Mirziyoyev commented on the foreign policy strategy of our country as follows: "The Central Asian region, which plays an important role in ensuring the national interests of our country, is a key priority of Uzbekistan's foreign policy. We remain committed to pursuing an open, friendly and pragmatic policy with our close neighbours Turkmenistan, Kazakhstan, Tajikistan and Kyrgyzstan "[1].

These changes in Uzbekistan's foreign policy have been recognized by the international community. For example, Victor Kim, a senior researcher at the Institute of Asian and African Studies, says: "The period from 2007 to 2016 can be described as a period of stagnation" for integration processes in Central Asia. With the election of Shavkat Mirziyoyev as President of Uzbekistan in December 2016, the situation in the region has changed dramatically, as well as the priorities of Uzbekistan's foreign policy "[6].

On September 22, 2017, the Miran International Hotel in Tashkent hosted a roundtable discussion on "Uzbekistan's foreign policy activities in the framework of the Action Strategy" with the participation of international and local experts. It was attended by a total of 26 experts from the United States, Russia, the United Kingdom, Sweden, Belgium, France, China, Japan, Pakistan and India. Lord Muhammad Iltaf Sheikh, a member of the House of Lords of the British Parliament who visited Tashkent, said that the people did not err in choosing the political successor of independent Uzbekistan, judging by the work done in Uzbekistan since the 2016 presidential election.

\section{CONCLUSION}

In general, today Uzbekistan is becoming a country that initiates the development of peace, cooperation, good neighbourliness, social and humanitarian ties between the Central Asian states.

\section{REFERENCES}

1. Mirziyoev Sh. M. (2017). We will resolutely continue our path of national development and raise it to a new level. Works I volume.-Tashkent: Uzbekistan. P.17.

2. Patel, F., Li, M., \& Sooknanan, P. (2011). Intercultural communication: Building a global community. SAGE Publications India.

3. https://soglom.uz/archives/9722

4. Alimova, M. F., Qalandarova, D. U., \& Alimjonova, L. (2020). Contemporary issues of religious studies in Uzbekistan. European Journal of Molecular \& Clinical Medicine, 7(2), 547-554.

5. Saydalieva, N. Z. (2021). Implementation of State Youth Policy 
The American Journal of Political Science Law and Criminology (ISSN - 2693-0803)

Published: August 25, 2021 | Pages: 12-16

Doi: https://doi.org/10.37547/tajpslc/Volume03Issueo8-03

at a New Stage of Development of Uzbekistan. International Journal of Multicultural and Multireligious Understanding, 8(4), 592-599.

6. Odil, M., \& Sherzod, K. (2020). Problems of religious tolerance and interethnic relations in Uzbekistan. Russia and the Muslim world, (3 (309)). 